\title{
THE EFFECT OF CREDIT RISK AND OPERATIONAL RISK ON PROFITABILITY WITH CAPITAL ADEQUACY VARIABLES AS A MEDIATING VARIABLE: A STUDY ON INDONESIAN STATE-OWNED BANKS FOR THE PERIOD OF 2015-2019
}

\author{
Peling Ida Ayu Adiatmayani*, Sedana Ida Bagus Panji \\ Faculty of Economics and Business, University of Udayana, Bali, Indonesia \\ *E-mail: atmapeling1@gmail.com
}

\begin{abstract}
Bank profitability illustrates the measure of the level of effectiveness of a bank's management in generating profits. High bank profitability shows a good bank's ability to earn profits and has a high contribution to the economic growth of a country. The average growth of profitability at state-owned banks in Indonesia for the 5 years 2015-2019 period has experienced a downward fluctuation. The purpose of this study was to analyze the effect of credit risk and operational risk on profitability with capital adequacy as a mediating variable. This study uses a non-probability sampling technique, namely approach sampling saturated with secondary data sources taken from the Quarterly Financial Statements at Bank BUMN (state-owned) of Indonesia for the period 2015 - 2019. The amount of data to be processed in this study consists of 80 observational data. The data analysis techniques used were path analysis and Sobel test to test the role of mediation with SPSS.. The results showed that credit risk had a negative and significant effect on profitability, operational risk had a negative and significant effect on profitability, credit risk had no effect on adequacy. capital, operational risk has a negative and significant effect on capital adequacy, capital adequacy has a positive and significant effect on profitability, capital adequacy is able to mediate the effect of credit risk on profitability, and capital adequacy is able to mediate the effect of operational risk on profitability. The theoretical implication of the results of this study is expected to add to the research literature on credit risk, operational risk, capital adequacy and profitability. The practical implications of this research are expected to provide a basic study of considerations in efforts to maximize profitability at Indonesian state-owned Banks by using the principle of prudence in managing credit risk management, mitigating operational risk to minimize cost expenditures and maintaining the level of bank capital adequacy for development purposes, business and to accommodate the risk of financial loss.
\end{abstract}

\section{KEY WORDS}

Profitability, credit risk, operational risk, capital adequacy.

The banking sector is one sector that has an important role in the economic growth of a country because in carrying out its activities, banks affect the entire national financial system in a country (Mendoza, 2017). Bank activities in carrying out their main business as financial intermediaries are collecting funds from the public and channeling funds to the public based on a sense of trust with the aim of achieving the maximum level of profitability (Kasmir, 2016: 3). Profitability level describes a measure of the effectiveness of a company's management in generating profits (Kasmir, 2019:212). Profitability shows the good or bad condition of a bank which will affect the trust of the parties associated with the bank (Rahmah, 2020). A high level of trust from parties related to the bank illustrates a good level of performance and a higher rate of return (Ajayi et al, 2019).

BI Regulation No.13/1/PBI/2011 dated January 5, 2011 concerning Assessment of Soundness of Commercial Banks shows that profitability which is a general indicator in determining the level of soundness is the ratio of Return On Assets (ROA). ROA shows the rate of return of the number of assets used in the company (Kasmir, 2016: 115). The higher the ROA, the better the bank's ability to earn profits and conversely, the lower the ROA, the smaller the company's ability to earn profits (Fahmi, 2016: 80). 
Based on the annual financial reports at Indonesia state-owned banks for the period 2015 - 2019, it can be seen that the development of the average ROA level at Indonesia state-owned banks for the period 2015 - 2019 experienced fluctuations that tended to decrease. The average ROA at Indonesia state-owned banks in 2015 was $2.89 \%$, decreased to $2.56 \%$ in 2016 then increased in 2017 by $0.15 \%$ to $2.71 \%$ and in 2018 increased again by 0 . $04 \%$ to $2.75 \%$. In 2019 the average ROA experienced a fairly high decline compared to the increase that occurred in the previous year, which was $0.48 \%$ to $2.27 \%$. The fluctuating decline in ROA shows that the state-owned bank is experiencing difficulties in maintaining the stability of profit growth every year. It is important to know the factors that affect the level of profitability of state-owned banks as a basis for consideration in managing and overcoming the risk of failure.

There are many factors that affect profitability in the banking sector. In general, these factors are categorized as bank industry-specific factors such as bank size, credit, capital, deposits, liquidity and Overhead cost management (Kawshala \& Kushani, 2017). Operational risk is an inherent risk that often arises due to the weakness of the bank's management control system which causes inefficiency of bank operations in their efforts to earn profits (Fahmi, 2018:54). Capital adequacy is an aspect that greatly influences the continuation and expansion of a bank business that needs to be managed properly to maximize profit (Kasmir, 2018:30).

Effective Credit Risk Management is an important component for the success of the Bank to obtain the maximum level of profit (Indonesian Bankers Association, 2018:39). The Bank's Credit Risk is measured by the Non-Performing Loan ratio (Dewi \& Badjra, 2020). Non-Performing Loan (NPL) is a ratio that shows the level of non-performing loans owned by banks (Arsy \& Sri, 2020). The increase in the NPL ratio indicates the cause of the decline in bank profitability. A high NPL ratio requires a larger Allowance for Earning Assets, reduces capital resources available for loans and reduces bank profitability (Idachaba et al, 2019). The higher this ratio, the worse the management of bank credit risk because the greater the number of non-performing loans, which causes interest income to decrease and profits also decrease (Anggriani \& Puji, 2020).

Based on the annual financial reports at Indonesia state-owned banks for the period 2015 - 2019 it is known that the average NPL at Indonesia state-owned banks fluctuates in every period from 2015 to 2019. In 2015, the average NPL of Indonesia state-owned banks was $2.61 \%$, increased to $2.96 \%$ in 2016 , then decreased in 2017 by $0.33 \%$ to $2.63 \%$ and decreased again by $0.21 \%$ in 2018 to $2.42 \%$. In 2019 , the average NPL of Indonesian BUMN Banks experienced a fairly high increase compared to the decline in the previous year, which was $0.51 \%$ to $2.93 \%$. This shows that Indonesian State-Owned Banks have difficulty maintaining the level of non-performing loans every year so that they do not fluctuate which tends to increase.

Several studies on the effect of the NPL variable on ROA showed different research results. The effect of NPL on ROA researched by Ariwidanta \& Wiksuana (2018), Kingu \& Raphael (2018), Shabani et al (2019), Idachaba et al (2019), Tangngisalu et al (2020), and Dewi \& Badjra (2020) show the result that NPL has a negative and significant effect on ROA. Research by Balango et al., (2017) shows the results that NPL has a positive effect on ROA. The research of Syamni et al (2018), Soares \& Muhammad (2018), Sari \& Endri (2019), Anggriani \& Puji (2020), Liyana \& Emmy (2020), Arasy \& Sri (2020), and Rahmah (2020) showed results which are not significant between NPL and ROA.

Measurement of bank operational risk is measured using the ratio between Operating Costs and Operating Income (BOPO). This comparison is referred to as the BOPO ratio which shows the ability of bank management to control operational costs against operating income (Sari \& Endri, 2019). The smaller this ratio means the more efficient the operational costs incurred by the bank concerned so that the possibility of a bank in troubled conditions will be smaller. A low BOPO ratio will increase bank profitability (Idachaba et al, 2019).

Based on the annual financial reports at Indonesia state-owned banks for the period 2015 - 2019 it can be seen that the average BOPO development at Indonesia state-owned banks fluctuated during the five-year period 2015 - 2019. In 2015 and 2016 the average 
BOPO for Indonesia state-owned banks was $78.52 \%$ then the BOPO decreased in 2017 to $73.50 \%$ followed by another decline in 2018 to $72.67 \%$, but in 2019 the BOPO increased to $77.22 \%$. Several studies on the effect of BOPO on ROA showed different results. Research conducted by Christaria \& Ratnawati (2016), Sari \& Sulistyo (2018), Syamni et al (2018), Soares \& Muhammed (2018), Tanjung (2019), Idachaba et al (2019), Sari \& Endri (2019), Dewi \& Badjra (2020), Arasy \& Sri (2020), and Rahmah (2020) showed that BOPO results had a negative and significant effect on ROA. Research conducted by Yusuf (2017), Budiono (2017), Setiani et al (2018) shows that BOPO results have a positive effect on ROA. Wahrudin's research, Udin (2020) shows an insignificant relationship between BOPO and ROA.The ratio used to measure the level of bank capital adequacy is the Capital Adequacy Ratio (Anggriani, 2020). According to Kasmir, 2014:46 CAR is the ratio of capital to Risk Weighted Assets. The higher the CAR, the more flexible the bank is to place funds in risky productive assets (Arsy \& Sri, 2020). The higher the CAR reflects the greater the capital owned by the bank so that it affects the level of public trust which leads to an increase in bank profits (Sari \& Endri, 2019).

Based on the annual financial report at Indonesia state-owned banks for the period 2015 - 2019, it can be seen that the average development of CAR at Indonesian StateOwned Banks for the period 2015 - 2019 has increased from 18.92\% in 2015 to $21 \%$ in 2016. However, this increase in capital was not accompanied by an increase in ROA in the same year. Furthermore, the average CAR decreased from 2016 to 2018 by $21 \%$ in 2016 to $20.49 \%$ in 2017 and $19.72 \%$ in 2018. In 2019 the average CAR increased again to $20.24 \%$. According to Ajayi et al, 2019 an increase in bank capital will increase bank profitability because bank capital adequacy can facilitate bank operational activities in providing credit and cover potential losses that occur, so that there is a gap phenomenon between CAR and ROA in Indonesian BUMN Banks for the 2015-2019 period.

Several studies on the effect of CAR on ROA show different results. Research on the effect of CAR on ROA investigated by Ariwidanta \& Wiksuana (2018), Sari \& Sulistyo (2018), Syamni et al (2018), Shabani et al (2019), Anggriani \& Puji (2020), and Idachaba et al (2019) shows that CAR results have a significant positive effect on ROA. Research conducted by Mendoza et al (2017) and Sari \& Endri (2019) shows that CAR results have a negative effect on ROA. Research by Soares \& Muhammad (2018), Liyana \& Emmy (2020), Arasy \& Sri (2020) and Rahmah (2020) showed insignificant results between CAR and ROA.

Credit distribution in bank activities has an impact on the level of capital adequacy owned by banks. The borrower's failure to fulfill the agreed obligations will reduce the component of the Bank's capital adequacy to cover risk losses that occur due to interest failure to be collected (Kasmir, 2019:234). Research on the effect of NPL on CAR as studied by Ariwidanta \& Wiksuana (2018) shows that NPL has a significant negative effect on CAR because the high number of non-performing loans will increase the Allowance for Earning Assets (PPAP) from the equity owned, thereby reducing the share of participation which is a component capital adequacy. Research by Liyana \& Emmy (2020) shows that the results of NPL have no significant effect on CAR because guarantees from credit owned by a bank have a higher liquidity value without including the bank's capital component.

Bank Operational Activities with a high complexity of the bank's business in carrying out the applicable procedures and rules create operational risks for the Bank which will have an impact on the level of bank capital adequacy. System failure and malfunctioning of internal processes, human errors have an impact on the high operational costs incurred in carrying out operational activities (Indonesian Bankers Association, 2015: 239). High operational costs will reduce the level of capital adequacy owned by banks because capital is used to cover operational costs incurred. Research on the effect of BOPO on CAR studied by Fahlevi et al (2019) and Arasy \& Sri (2020) shows the results of BOPO have a significant negative effect on CAR because when operating costs are high, capital is used to cover operational costs, thereby lowering the CAR value. Research by Abusharba et al (2014) shows that the BOPO results have no significant effect on CAR.

Seeing the importance of assessing bank performance for maximizing bank profitability in supporting national development and the controversial results of the influence between 
NPL and BOPO on ROA, this research gap is the research gap. So the researcher wants to review it again to clarify and confirm the Effect of Credit Risk and Operational Risk on Profitability with Capital Adequacy as a Mediation Variable. Based on theory and empirical research, the conceptual framework can be described as follows:

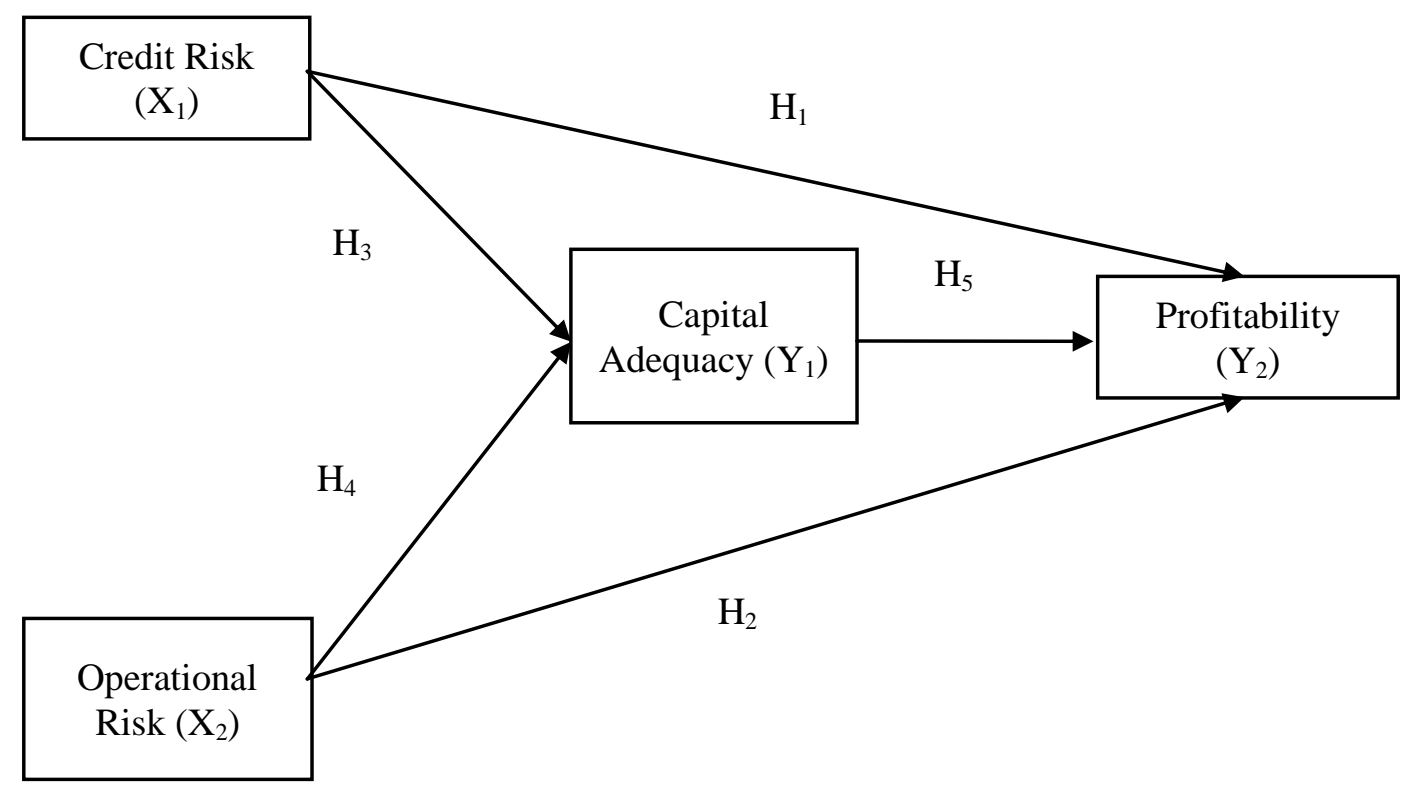

Figure 1 - Research conceptual framework

Based on Figure 1, the hypotheses of this study are:

$\mathrm{H} 1$ : Credit Risk has a negative effect on Profitability;

H2: Operational Risk has a negative effect on Profitability;

H3: Credit Risk has a negative effect on Capital Adequacy;

H4: Operational Risk has a negative effect on Capital Adequacy;

H5: Capital Adequacy has a positive effect on Profitability;

H6: Capital Adequacy is able to mediate the influence of Credit Risk on Profitability;

H7: Capital Adequacy is able to mediate the effect of Operational Risk on Profitability.

\section{METHODS OF RESEARCH}

This study uses a quantitative approach in the form of associative research with the type of explanatory research. The sampling technique used is Saturated Sampling with the data used in the form of secondary data taken from the Monthly Financial Reports at Indonesia state-owned banks for the period $2015-2019$. The method used is path analysis with the SPSS program. Location and Time This research was conducted at 4 Indonesian state-owned banks: PT. Bank Negara Indonesia (Persero) Tbk, PT Bank Rakyat Indonesia (Persero) Tbk, PT Bank Mandiri (Persero) Tbk, and PT. State Savings Bank (Persero) Tbk during the period 2015-2019. The selection of this research location was based on the researcher's considerations because of the decline in the average fluctuating profitability developments in the 4 Indonesian state-owned banks during the 2015 - 2019 period.

\section{RESULTS AND DISCUSSION}

Based on the results of the descriptive statistical test in Table 1, it shows that the number of $\mathrm{N}$ is 80 data. This means that there are 80 observational data studied, consisting of 4 banking companies during the 5 year research period, namely 2015-2019 in four quarters. The data in Table 5.1 shows that the ROA variable obtained a minimum value of $0.13 \%$ contained in Bank BTN in the third quarter of 2019 , which means that during the 5 
research periods from 2015-2019 Bank BTN had the lowest profitability compared to other banks. The ROA variable has a maximum value of $4.19 \%$ contained in $\mathrm{BRI}$ bank in the fourth quarter of 2015, which means that during the 5 research periods from 2015-2019, BRI bank has the highest profitability compared to other banks. The average value of ROA is $2.619 \%$ with a standard deviation of $0.89 \%$. The NPL variable obtained a minimum value of $1.75 \%$ which was found at BNI Bank in the second quarter of 2019, which means that during the 5 research periods from 2015-2019 BNI Bank had the lowest credit risk compared to other banks. The NPL variable has a maximum value of $4.78 \%$ contained in Bank BTN in the first quarter of 2015, which means that during the 5 research periods from 2015-2019 Bank BTN has the highest credit risk compared to other banks. The average value of NPL is $2.79 \%$ with a standard deviation of $0.705 \%$. The BOPO variable obtained a minimum value of $63.01 \%$ which was found in Bank Mandiri in the first quarter of 2018, which means that during the 5 research periods from 2015-2019, Bank Mandiri had the lowest operational risk compared to other banks. The BOPO variable has a maximum value of $98.12 \%$ found in Bank BTN in the third quarter of 2019, which means that for 5 research periods from 2015-2019 Bank BTN has the highest operational risk compared to other banks. The average value of BOPO is $74.908 \%$ with a standard deviation of $7.562 \%$. The CAR variable obtained a minimum value of $14.78 \%$ found in Bank BTN in the second quarter of 2015, which means that during the 5 research periods from 2015-2019 Bank BTN had the lowest capital adequacy compared to other banks. The CAR variable has a maximum value of $22.96 \%$ found in BRI banks in the fourth quarter of 2017, which means that during the 5 research periods from 2015-2019, BRI Bank has the highest capital adequacy compared to other banks. The average value of CAR is $19.602 \%$ with a standard deviation of $1.98 \%$.

Table 1 - Descriptive statistics

Descriptive Statistics
\begin{tabular}{|l|l|l|l|l|l|}
\hline & $N$ & Minimum & Maximum & Mean & Std. Deviation \\
\hline ROA & 80 & 13 & 4.19 & 2.6193 & 89052 \\
NPL & 80 & 1.75 & 4.78 & 2.7969 & 70510 \\
BOPO & 80 & 63.01 & 98.12 & 74.9081 & 7.56202 \\
CAR & 80 & 14.78 & 22.96 & 19.6025 & 1.98306 \\
Valid N (listwise) & 80 & & & & \\
\hline
\end{tabular}

Source: Data processed, 2021.

Testing the data in this study uses path analysis techniques, where path analysis is an extension of multiple linear regression analysis to test the causal relationship between 2 or more variables.

The path coefficient calculation was carried out using SPSS 18.0 for Windows software, and the results are shown in Table 2 below:

Table 2 - Path Analysis Test Results (Structure 1)

\begin{tabular}{|c|c|c|c|c|c|}
\hline \multirow{2}{*}{ Variables } & \multicolumn{2}{|c|}{ Unstandardized Coefficients } & \multirow{2}{*}{$\begin{array}{l}\text { Standardized Coefficients } \\
\text { Beta }\end{array}$} & \multirow[b]{2}{*}{ t test } & \multirow[b]{2}{*}{ Sig. uji t } \\
\hline & $\mathrm{B}$ & Std. Error & & & \\
\hline (Constant) & 31.533 & 1.926 & & 16.372 & .000 \\
\hline NPL & .533 & .042 & .189 & 1.556 & .124 \\
\hline BOPO & -.179 & .032 & -.683 & -5.612 & .000 \\
\hline
\end{tabular}

Source: Data processed, 2021.

Table 3 Path Analysis Test Results (Structure 2)

\begin{tabular}{llllll}
\hline \multirow{2}{*}{ Variables } & \multicolumn{2}{l}{ Unstandardized Coefficients } & Standardized Coefficients & \multirow{2}{*}{ t test } & \multirow{2}{*}{ Sig. uji t } \\
\cline { 2 - 5 } & $\mathrm{B}$ & Std. Error & Beta & 10.492 & .000 \\
(Constant) & 8.671 & .826 & & -2.366 & .021 \\
NPL & -.167 & .070 & -.132 & -11.696 & .000 \\
BOPO & -.090 & .008 & .763 & 2.527 & .014 \\
CAR & .058 & .023 & .130 & & \\
\hline
\end{tabular}

Source: Data processed, 2021. 
Based on the results of the path analysis of substructure 1 as presented in Table 2, the following structural equations can be made: $Y 1=0,533 X_{1}-0,179 X_{2}+e_{1}$.

Based on the results of the analysis of substructure path 2 as presented in Table 3 , the following structural equations can be made: $Y 2=-0,167 X_{1}-0,090 X_{2}+0,058 Y 1+e_{2}$.

Table 4 - Results of the Coefficient of Determination

\begin{tabular}{llll}
\hline Structure & Equation & $R$ Square & Adjusted $R$ Square \\
\hline 1 & $\mathrm{Y} 1=0,533 \mathrm{X}_{1}-0,179 \mathrm{X}_{2}+\mathrm{e}_{1}$ & 0,335 & 0,318 \\
2 & $\mathrm{Y} 2=-0,167 \mathrm{X}_{1}-0,090 \mathrm{X}_{2}+0,058 \mathrm{Y} 1+\mathrm{e}_{2}$ & 0,866 & 0,861 \\
\hline
\end{tabular}

Source: Data processed, 2021.

Table 4 shows the structural equation 1 (path analysis 1) the magnitude of the influence of the independent variable on the dependent variable which is indicated by the value of determination (Adjusted $R$ Square) of 0.318 which means that $31.8 \%$ of variations in capital adequacy are influenced by variations in credit risk (X1) and operational risk (X2), while the remaining $68.2 \%$ is explained by other factors not included in the model.

While in structural equation 2 (path analysis 2) the magnitude of the influence of the independent variable on the dependent variable is indicated by the value of determination (Adjusted R Square) of 0.861 which means that $86.1 \%$ of the variation in profitability is influenced by variations in credit risk (X1), operational risk (X2), and capital adequacy (Y1), while the remaining $13.9 \%$ is explained by other factors not included in the model.

Based on the substructure 1 and substructure 2 models, a final path diagram model can be drawn up. Before compiling the final path diagram model, first calculate the standard error values as follows:

$$
\begin{aligned}
\mathrm{e}_{\mathrm{i}} & =\sqrt{1-\mathrm{R}_{\mathrm{i}}^{2}}=0,826 \\
\mathrm{e}_{2} & =\sqrt{1-R_{2}{ }^{2}}=0,373
\end{aligned}
$$

Based on the calculation of the effect of error (ei), the effect of error (e1) is 0.806 and the effect of error $(\mathrm{e} 2)$ is 0.373 . The results of the coefficient of total determination are as follows:

$$
\mathrm{R}_{\mathrm{m}}^{2}=1-\left(\mathrm{e}_{1}\right)^{2}\left(\mathrm{e}_{2}\right)^{2}=0,905
$$

The total determination value of 0.905 means that $90.5 \%$ of the variation in profitability is influenced by variations in credit risk, operational risk, and capital adequacy, while the remaining $9.5 \%$ is explained by other factors not included in the model.

Table 5 - Direct and Indirect Effects and Total Effects of Research Variables

\begin{tabular}{llll}
\hline Variable Effect & Direct Effect & Indirect Influence Through Capital Adequacy $(\mathrm{Y})$ & Total Effect \\
\hline $\mathrm{X}_{1} \rightarrow \mathrm{Y} 1$ & 0,533 & - & 0,533 \\
$\mathrm{X}_{2} \rightarrow \mathrm{Y} 1$ & $-0,179$ & - & $-0,179$ \\
$\mathrm{Y} 1 \rightarrow \mathrm{Y} 2$ & 0.058 & - & 0.058 \\
$\mathrm{X}_{1} \rightarrow \mathrm{Y} 2$ & $-0,167$ & $(0,533 \times 0,058)=0,0309$ & $-0,136$ \\
$\mathrm{X}_{2} \rightarrow \mathrm{Y} 2$ & $-0,090$ & $(-0,179 \times 0,058)=-0,010$ & $-0,100$ \\
\hline
\end{tabular}

Source: Data processed, 2021.

Sobel test is an analytical tool to test the significance of the indirect relationship between the independent variable and the dependent variable mediated by the mediator variable. If the calculated value of $Z$ is greater than 1.96 (with a confidence level of 95 percent), then the mediator variable is considered to significantly mediate the relationship between the dependent variable and the independent variable.

Testing the indirect effect of the credit risk variable (X1) on the Profitability variable (Y2) through the Capital Adequacy variable (Y1) as follows:

$$
S_{b 1 b 5}=\sqrt{b 5^{2} S_{b 1}^{2}+b 1^{2} S_{b 5}^{2}}=0,012499
$$


Where: $\mathrm{Sb} 1 \mathrm{~b} 5=$ the size of the indirect standard error; Sb1 = standard error coefficient b1; Sb5 = standard error coefficient b5; b1 = path $\mathrm{X} 1$ to $\mathrm{Y} 1$; b5 = path $\mathrm{Y} 1$ to $\mathrm{Y} 2$; b1 b5 = path X1 to $\mathrm{Y} 1$ (b1) with path $\mathrm{Y} 1$ to $\mathrm{Y} 2$ (b5).

To test the significance of the indirect effect, calculate the $z$ value of the ab coefficient with the following formula:

$$
Z=\frac{b 1 b 5}{S b 1 b 5}=2,4734
$$

Therefore, $\mathrm{Z}$ test is $2.4734>1.96$. This means that capital adequacy $(\mathrm{Y} 1)$ is a variable that mediates credit risk (X1) on profitability (Y2) or in other words credit risk has an indirect effect on profitability.

Testing the indirect effect of the operational risk variable (X2) on the Profitability variable (Y2) through the Capital Adequacy variable (Y1) as follows:

$$
S_{b 2 b 5}=\sqrt{b 5^{2} S_{b 2}^{2}+b 2^{2} S_{b 5}^{2}+S_{b 2}^{2} S_{b 5}^{2}}=0,004516
$$

Where: Sb2b5 = the size of the indirect standard error; Sb2 = standard error coefficient b2; $\mathrm{Sb} 5=$ standard error coefficient $\mathrm{b} 5 ; \mathrm{b} 2=$ path $\mathrm{X} 2$ with respect to $\mathrm{Y} ; \mathrm{b} 5=$ path $\mathrm{Y}$ to $\mathrm{Z} ; \mathrm{b} 2 \mathrm{~b} 5=$ path $X 2$ to $Y$ (b2) with path $Y$ to $Z$ (b5).

To test the significance of the indirect effect, calculate the $z$ value of the ab coefficient with the following formula:

$$
Z=\frac{b 2 b 5}{S b 2 b 5}=2,2989
$$

Therefore, the $Z$ test is $2.2989>1.96$. This means that capital adequacy $(Y)$ is a variable that mediates operational risk (X2) on profitability $(\mathrm{Y} 2)$ or in other words operational risk has an indirect effect on profitability through capital adequacy.

The Effect of Credit Risk on Profitability. Credit risk is a risk caused by the inability of debtors to fulfill their obligations as required by creditors (Fahmi, 2018: 104). Credit risk is the biggest risk experienced by the bank so that good credit risk management is needed to minimize the cost of losses that may occur (Fahmi, 2018: 106).

Credit risk is proxied by the NPL (Non Performing Loan) ratio to measure the risk of credit failure by debtors to total credit which represents how many bank loans become nonperforming (Ariwidanta \& Wiksuana, 2018). The higher the NPL ratio, the worse the Credit Risk management carried out by the bank because a high NPL indicates the high number of non-performing loans owned by the bank which leads to a decrease in profitability (Sari \& Endri, 2019).

The first hypothesis testing conducted on the effect of credit risk on profitability in this study, obtained the results that credit risk has a negative and significant effect on profitability, which means that if there is an increase in credit risk, the profitability will decrease. These results are in line with Kasmir's statement, 2018: 80 in his book entitled "Bank Marketing" explaining that the amount of credit disbursed will determine the level of bank profits. Hery, 2020: 39 in the book "Basics of Banking" states that the purpose of providing credit cannot be separated from the mission of the bank being established, one of which is to seek profit in the form of interest received by the bank as remuneration and credit administration fees charged to customers.. If the bank is not able to manage credit properly, the bank will experience losses. So, effective Credit Risk management is an important component for the success of the Bank to obtain the maximum level of profit (Indonesian Bankers Association, 2018:39). Based on BI Circular No. 6/23/DPNP in 2004, Bank Indonesia set the criteria for an NPL ratio below $5 \%$ as a good predicate for the health of the Bank.

The results of the study which show a negative and significant relationship between credit risk and profitability are in line with data on the development of the average NPL ratio and ROA ratio in state-owned banks for the 5-year period 2015-2019. When there was an increase in the NPL ratio in 2015 by $2.61 \%$ to $2.96 \%$ in 2016 it was accompanied by a 
decrease in the ROA ratio in the same year by $2.89 \%$ to $2.56 \%$ and a decrease in the NPL ratio in 2017 by $0.33 \%$ to $2.63 \%$ accompanied by an increase in the ROA ratio in the same year by $0.15 \%$ to $2.71 \%$.

The results of this study are supported by research conducted by Ariwidanta \& Wiksuana (2018), Kingu \& Raphael (2018), Shabani et al (2019), Idachaba et al (2019), Tangngisalu et al (2020), Dewi \& Badjra (2020) and research by Soares \& Muhammad, 2018 which shows the results that NPL has a negative and significant effect on ROA.

Effect of Operational Risk on Profitability. Operational Risk shows the level of efficiency risk between operating costs and operating income. The condition of the occurrence of operational risk is strongly influenced by the high and low quality of management maturity owned by the manager of a company (Fahmi, 2018: 53). Efficiency theory explains that all the efficiencies of business activities will increase profitability and vice versa (Sari \& Sulistyo, 2018). A bank can work at lower costs and with higher profits if the bank makes better use of its inputs and converts them into outputs in the most efficient way possible (Indonesian Bankers Association, 2014:235).

The ratio used to measure the level of Operational Risk of a bank in carrying out its operations is the ratio of Operating Costs to Operating Income (Sari \& Endri, 2019). The smaller the BOPO, the more efficient the operational costs incurred by the bank and the possibility of the bank being in a problematic condition is also getting smaller so that it is able to obtain better profits (Soares \& Muhammad, 2018).

Testing the second hypothesis on the effect of operational risk on profitability in this study, obtained the results that operational risk has a negative and significant effect on profitability, which means that if there is an increase in operational risk, the profitability will decrease. These results are in line with Fahmi's statement, 2018:54 in his book entitled "Risk Management" explaining that operational risk is an important aspect that must be managed in an effort to realize a healthy and sustainable bank financial performance (Fahmi, 2018:54).

Efficiency theory explains that all the efficiencies of business activities will increase profitability and vice versa (Sari \& Sulistyo, 2018). The smaller this ratio means the more efficient the operational costs incurred by the bank, the higher the chance for the bank to make a profit (Idachaba et al, 2019). Based on BI SE No.6/23/DPNP dated 31 May 2004, Bank Indonesia determined that the ideal condition for BOPO should not exceed $96 \%$. The efficiency of bank operational costs is very important to be able to increase the level of profit to be achieved. A bank can work at lower costs and with higher profits if the bank makes better use of its inputs and converts them into outputs in the most efficient way possible (Indonesian Bankers Association, 2014:235).

The results of this study are supported by research conducted by Christaria \& Ratnawati (2016), Sari \& Sulistyo (2018), Syamni et al (2018), Soares \& Muhammed (2018), Tanjung (2019), Idachaba et al (2019), Sari \& Endri (2019), Dewi \& Badjra (2020), Arasy \& Sri (2020), and Rahmah (2020) which show that the BOPO results have a negative and significant effect on ROA.

The Effect of Credit Risk on Capital Adequacy. Credit risk is a form of the inability of a company, institution, institution or individual to complete their obligations in a timely manner (Fahmi, 2018: 18). Credit risk is proxied by the ratio of NPL (Non Performing Loan). The higher the NPL ratio, the worse the management of bank credit risk, which causes the number of non-performing loans to increase and banks must increase the cost of reserves to bear the costs of losses (Sari \& Endri, 2019).

Capital is used as a reserve to cover credit costs, especially the risks incurred to cover costs incurred due to the debtor's failure to fulfill his obligations to the bank (Kasmir, $2019: 234$ ). CAR is a ratio used to measure the level of bank capital adequacy (Kasmir, 2019:234). If the NPL ratio continues to increase, it will have an impact on the decline in the CAR ratio of the bank because capital is used to cover the costs of losses incurred.

The third hypothesis testing conducted on the effect of credit risk on capital adequacy in this study obtained the result that credit risk has no effect on capital adequacy, which means the third hypothesis is rejected. The test results are not significant between the ratio of credit risk and capital adequacy at state-owned banks, which means that the increase in 
non-performing credit risk does not affect the level of bank capital adequacy because the increase in credit risk is relatively smaller than the increase in bank capital adequacy obtained from outside income the main activity of the bank. This is shown in the data on the average development of NPL and CAR of BUMN Banks for the 2015-2019 period. The increase in the average NPL of Indonesian SOEs from 2015 to 2016 was $0.35 \%$ from $2.61 \%$ to $2.96 \%$ which was still relatively lower than the increase in the CAR ratio from 18.92 to $21 \%$ in the same year which is $2.08 \%$. The increase in the average NPL ratio which was quite high was also shown in 2019 of $0.51 \%$, from $2.42 \%$ to $2.93 \%$ which was still relatively lower than the increase in the CAR ratio in the same year, which was $19.72 \%$ to $20.24 \%$ by $0.52 \%$ so that the increase in credit risk does not have a significant impact on the bank's capital adequacy.

The results of this insignificant study explain that state-owned banks are able to manage the risk of non-performing loans without having to include components of capital adequacy owned by collateral from loans that have a higher liquidity value to cover loans classified as non-performing. This is indicated by the NPL value of state-owned banks during the research year period, which was far below the minimum limit set by BI Circular Letter No. $6 / 23 /$ DPNP in 2004 which is $5 \%$. The average level of NPL owned by state-owned banks for the 2015-2019 period is $2.79 \%$, based on the criteria for rating the NPL component of Bank Indonesia with the predicate of Good.

The results of this study are supported by Permatasari \& Amboningtyas (2017), Supeni (2019) and Liyah Liyana \& Emmy Indrayani (2020) which showed that NPL results have no significant positive effect on CAR.

Effect of Operational Risk on Capital Adequacy. Operational Risk shows the level of efficiency risk between operational costs and operating income (Fahmi, 2018: 53). Operational risk as measured by the ratio of Operating Costs and Operating Income (BOPO) is a factor that directly affects the level of costs incurred by banks (Idachaba et al, 2019). Bank capital is funds issued to finance bank operational activities every day (Fahmi, 2018:64). High operational risk indicates the inefficiency of the bank in carrying out its operational activities which incur high costs and reduce the level of bank capital adequacy. Poor operational risk management shows the poor performance of bank management in making efficiency of its operational costs to its operating income (Indonesian Bankers Association, 2016: 60).

The fourth hypothesis testing conducted on the effect of operational risk on capital adequacy in this study, obtained the results that operational risk has a negative and significant effect on capital adequacy, which means that if there is an increase in operational risk, the capital adequacy of the bank will decrease. These results are in line with Fahmi's statement, 2018:64 in his book entitled "Risk Management" explaining that in carrying out its operational activities, banks use capital to finance each of their operational activities. Hery, 2019:169 states that banks use capital to meet the needs that support their operational activities so that high operational costs cause bank capital to decrease. According to Kasmir, 2019:247 the lower the BOPO, the better the performance of the bank's management because it is more efficient in using existing resources within the company. Bank management must understand the sources of operational risk, processes, and work systems to be able to identify Operational Risk in order to monitor the effectiveness of controls on Operational Risk (Indonesian Bankers Association, 2016: 60).

The results of this study are supported by research by Fahlevi et al (2019) and Arasy \& Sri (2020) showing the results of BOPO have a significant negative effect on CAR because when operating costs are high, capital is used to cover operational costs, thereby lowering CAR value.

Effect of Capital Adequacy on Profitability. Bank capital in principle has three main functions, namely operational, protection and regulatory functions (Hery, 2019:169). As one of the most fundamental aspects in implementing the prudential principle, banks must meet their capital adequacy. Adequate bank capital is an important component to cover potential unexpected losses and as a reserve in the event of a banking crisis (Indonesian Bankers Association, 2016: 159). Banks need to have sufficient capital to carry out their operational 
activities properly. Capital Adequacy Ratio (CAR) is a ratio used to measure capital and weighted asset write-off reserves (Kasmir, 2019:234). CAR focuses on capital which shows the bank's ability to provide funds for business development purposes and to accommodate the risk of financial losses arising from bank operational activities (Arsy \& Sri, 2020).

The fifth hypothesis testing conducted on the effect of capital adequacy on profitability in this study, obtained the results that capital adequacy has a positive and significant effect on profitability which means that if there is an increase in bank capital adequacy, the profitability of the bank will increase. These results are in line with the Buffer Theory of Capital Adequacy which explains that capital adequacy above the minimum requirement is an important factor in increasing profitability for the smooth operation of bank operations. According to Hery, 2019:169 in a book entitled "Banking Management" explains that bank capital adequacy is an important component for smooth operations, covering potential losses from financial and economic crises as well as excessive credit growth, as well as increasing public confidence in the ability of banks to meet their needs. obligations that lead to increased profits. The higher the capital, the better the bank's ability to bear the risk of any risky credit or productive assets and be able to finance operational activities and make a sizeable contribution to profitability. (Idachaba et al, 2019). Bank Indonesia Regulation Number 10/15/PBI/2008 states that every bank is required to provide a minimum capital of $8 \%$ of risk-weighted assets (RWA). The results of this study are also in line with the results of descriptive statistical tests which show that the highest CAR ratio is owned by Bank BRI of $22.96 \%$, accompanied by the acquisition of the highest ROA ratio of $4.19 \%$. This explains that an increase in bank capital will increase bank profitability because bank capital adequacy can facilitate bank operational activities in providing credit and cover potential losses that occur (Ajayi et al, 2019). The results of this study are supported by research by Ariwidanta \& Wiksuana (2018), Sari \& Sulistyo (2018), Syamni et al (2018), Shabani et al (2019), Anggriani \& Puji (2020), and Idachaba et al (2019). CAR has a significant positive effect on ROA.

Capital Adequacy is able to mediate the influence of Credit Risk on Profitability. Capital adequacy is one of the most basic aspects in implementing the prudential principle in lending (Hery, 2019:16). Capital Adequacy Ratio (CAR) is a ratio used to measure capital (Kasmir, 2019:234). The higher the capital, the better the bank's ability to bear the risk of any credit or risky productive assets that make a large enough contribution to profitability (Idachaba et al, 2019). Non Performing Loan (NPL) is a ratio that shows the level of non-performing loans to total loans owned by banks. If a bank's NPL continues to increase, it will affect the bank's capital because it must provide funds for Allowance for Earning Assets (Ariwidanta \& Wiksuana, 2018).

The sixth hypothesis testing conducted on the role of capital adequacy in mediating the effect of credit risk on profitability in this study, obtained the results that capital adequacy was able to mediate the effect of credit risk on profitability. These results are in line with the Buffer Theory of Capital Adequacy which explains that bank capital adequacy can reduce the possibility of falling below the minimum capital requirements and can protect banks from the risk of excessive credit growth and potential losses from financial and economic crises (Adamgbo, 2019). High capital adequacy will support the ability of banks to disburse credit loans and expand other bank business activities to obtain higher profits. According to Henry, 2019:164 in a book entitled "Banking Management" explains that bank capital adequacy is important for smooth financing of operational activities and absorbing potential losses from excessive credit growth. The higher the capital, the better the bank's ability to finance operational activities and make a sizeable contribution to profitability (Idachaba et al, 2019).

Banks that have a high CAR ratio can protect the bank from various forms of business risk, such as a high level of non-performing loans. Banks with good capital adequacy can anticipate all forms of business risk so that banks can continue to operate in a healthy and sustainable manner (Henry, 2019:171). In this way, CAR can mediate NPL on ROA. The results of this study are supported by research conducted by Liyana \& Emmy, 2020, which shows that CAR is able to mediate the effect of NPL on ROA. 
Capital Adequacy is able to mediate the effect of Operational Risk on Profitability. The aspect of bank capital is a factor that plays a significant role in the smooth running of Bank activities in covering risks for achieving optimal bank profitability (Indonesian Bankers Association, 2014: 245). Banks with capital adequacy above the required minimum capital ratio can better support bank operations. Operational activities with high operational risk indicate the inefficiency of the bank in carrying out its operational activities which incur high costs and reduce the level of bank capital adequacy.

The seventh hypothesis testing conducted on the role of capital adequacy in mediating the effect of operational risk on profitability in this study, obtained the result that capital adequacy was able to mediate the effect of operational risk on profitability. These results are in line with the Buffer Theory of Capital Adequacy which explains that banks with capital adequacy above the minimum requirements can support bank operations and increase profits. Adequate capital becomes a buffer to absorb unexpected losses from its activities so as to support banks to continue to operate in a healthy and proper manner (Indonesian Bankers Association, 2014: 244). According to Fahmi, 2018:64 in his book entitled "Risk Management" explains that capital is used to finance bank operational activities every day. High operational risk in carrying out bank activities indicates the bank's inefficiency in carrying out its operational activities which incur high costs and reduce the level of bank capital adequacy. The decline in Capital Adequacy causes limited capital for the smooth operation of the Bank in obtaining profits so that capital adequacy is able to mediate the effect of BOPO on profitability. The results of this study are supported by the research of Atmoko \& Fathoni, 2018 which obtained the results that CAR was able to mediate the effect of BOPO on ROA.

Limitations. The limitation of this study is that the number of samples in this study is limited to 4 state-owned banks in Indonesia so that the conclusions cannot be generalized to all banking companies in Indonesia. The variables used in this study only use 3 financial variables, namely credit risk (NPL), operational risk (BOPO) and capital adequacy (CAR) on bank profitability.

\section{CONCLUSION AND SUGGESTIONS}

The conclusion in this study is that credit risk has a negative and significant effect on profitability at state-owned banks for the period 2015 - 2019. Operational risk has a negative and significant effect on profitability at state-owned banks for the period 2015 - 2019. Credit risk has no effect on capital adequacy at state-owned banks for the period 2015-2019. 2015 2019. Operational risk has a negative and significant effect on capital adequacy at stateowned banks for the period 2015 - 2019. Capital adequacy has a positive and significant effect on profitability at state-owned banks for the period 2015 - 2019. Capital adequacy is able to mediate the effect of credit risk on profitability in State-owned banks for the 2015 2019 period. Capital adequacy is able to mediate the effect of operational risk on profitability at state-owned banks for the 2015 - 2019 period.

Suggestions that can be given are that state-owned banks are advised to pay attention to the level of credit risk, operational risk and capital adequacy owned. State-owned banks are expected to have a low level of credit risk by managing credit distribution. Apply the precautionary principle of $5 \mathrm{C}$ (Character, Capacity, Capital, Condition, Collateral) and $7 \mathrm{P}$ (Personality, Purpose, Party, Payment, Prospect, Profitability, Protection) analysis in assessing creditworthiness. State-owned banks are expected to have a low level of operational risk by managing policies related to risk mitigation in each bank's products and services, segregating the appropriate functions and responsibilities of human resources and conducting regular evaluations. State-owned banks are expected to maintain the level of capital adequacy for business development purposes and accommodate the risk of financial losses arising from bank operational activities. Further researchers are advised to use or develop other variables that are thought to be capable of influencing or mediating variables to increase bank profitability. In addition, increasing the number of company samples is also highly recommended so that it will increase the generalizability of the research results. 


\section{REFERENCES}

1. Abusharba, Mohammed T, Iwan Triyuwono dkk. 2014. Determinants of Capital Adequacy Ratio (CAR) in Indonesian Islamic Commercial Banks. Global Review of Accounting and Finance. 4 (1) $159-170$.

2. Alfian, Alfan. 2009. Menjadi Pemimpin Politik. Jakarta: PT. Gramedia Pustaka Utama.

3. Ajayi, Samuel Olatayo, Ajayi, Henry Fol dkk. 2019. Effect of Capital Adequacy Ratio (CAR) on Profitability of Deposit Money Banks (DMB's): A Study of DMB's with nternational Operating License in Nigeria. Research Journal of Finance and Accounting. 10 (10) 84-91.

4. Anggriani, Rita \& Puji Muniarty. 2020. The Effect of Non-Performing Loans (NPL) and Capital Adequacy Ratio (CAR) on Profitability (ROA) at PT. Bank Central Asia (BCA), TBK. Ilomata International Journal of Management. 1(3) 121-126.

5. Arasy, Ruh Amir \& Sri Setya Handayani. 2020. Influence of Capital Adequacy Ratio (Car), Loan To Deposits Ratio (Ldr), Operational Efficiency Ratio (Oer), And NonPerforming Loan (Npl) On Return On Assets (Roa) Of Soes Bank In 2016 To 2018. International Journal of Economics, Commerce and Management. 8 (6) 308-320.

6. Ariwidanta \& Wiksuana. 2018. The Effect of Credit And Liquidity Risk On Bank Profitability And Capital Adequacy Ratio As Mediation Variables In Indonesia. Russian Journal of Agricultural and Socio-Economic Science, 9(81): 165 -171.

7. Balango, T. K., \& Rao, M. (2017). The effect of NPL on profitability of banks with reference to commercial bank of Ethiopia. Business and Management Research Journal, 7(5), 45-50.

8. Bank Indonesia. 2004. Surat Edaran Bank Indonesia Nomor 6/23/DPNP Perihal Sistem Penilaian Tingkat Kesehatan Bank. www.bi.go.id.

9. Bank Indonesia. 2011. Peraturan Bank Indonesia Nomor 13/1/PBI/2011 tanggal 5 Januari 2011 tentang Penilaian Tingkat Kesehatan Bank Umum. Jakarta.

10. Bank Indonesia. 2011. Surat Edaran Bank Indonesia Nomor 13/24/DPNP tanggal 25 Oktober 2011 tentang Penilaian Tingkat Kesehatan Bank Umum. Jakarta.

11. Bank Negara Indonesia, PT. Laporan Keuangan Tahunan 2015, 2016, 2017, 2018 and 2019. diakses di www.bni.co.id pada 13 November 2020.

12. Bank Rakyat Indonesia, PT. Laporan Keuangan Tahunan 2015, 2016, 2017, 2018 and 2019. diakses di www.bni.co.id pada 13 November 2020.

13. Bank Tabungan Negara, PT. Laporan Keuangan Tahunan 2015, 2016, 2017, 2018 and 2019. diakses di www.bni.co.id pada 13 November 2020.

14. Bank Mandiri, PT. Laporan Keuangan Tahunan 2015, 2016, 2017, 2018 and 2019. diakses di www.bni.co.id pada 13 November 2020.

15. Bringham and Daves. 2010. Intermediate Financial Management. Tenth Edition. Cengage Learning: South Western.

16. Budiono. 2017. Analisa Pengaruh Non Performing Loan (NPL), BOPO and Net Interest Margin (NIM) Terhadap Return On Asset (ROA) Pada Bank Perkreditan Rakyat Konvensional Di Jawa Timur. Jurnal Mutiara Madani. 4 (1) 26-34.

17. Budisantoso T. and Nuritomo. 2014. Bank and Lembaga Keuangan Lain. Edisi Ketiga. Jakarta: Salemba Empat.

18. Christaria, Fiola \& Ratnawati Kurnia. 2016. The Impact of Financial Ratios, Operational Efficiency and Non- Performing Loan Towards Commercial Bank Profitability. Global Academy of Training \& Research (GATR) Enterprise. 1(1) $43-50$.

19. Dewi, Komang Citra \& Ida Bagus Badjra. 2020. The Effect Of Npl, Ldr And Operational Cost Of Operational Income On ROA. American Journal of Humanities and Social Sciences Research. 4 (7) 171-178.

20. Fahlevi, Mochammad, Dasih Irma dkk. 2019. The Effect Of Financial Performance, External Factors, And Operational Ratio On Car Ratio Of Sharia Commercial Banks In Indonesia. Journal of Research in Business, Economics and Management. 12 (2): 2348-2355.

21. Fahmi, Irham. 2015. Analisis Laporan Keuangan. Bandung: Alfabeta. 
22. Fahmi, Irham. 2016. Pengantar Manajemen Keuangan. Bandung: Alfabeta.

23. Fahmi, Irham. 2018. Manajemen Risiko. Bandung: Alfabeta.

24. Garson, G. D. 2016. Partial Least Squares: Regression and Structural Equation Models.Asheboro, Nort Country: Statistical Associates Publishers.tam.

25. Ghozali. 2016. Aplikasi Analisis Multivariete Dengan Program IBM SPSS. Semarang: Badan Penerbit Universitas Diponegoro.

26. Hamidah. 2019. Manajemen Keuangan. Jakarta: Mitra Wacana Media.

27. Hanafi, Mamduh M. 2016. Manajemen Keuangan. Edisi kedua, Cetakan pertama. Yogyakarta: BPFE.

28. Haryanto, S. B., \& Widyarti, E. T. 2017. Analisis pengaruh NIM, NPL, BOPO, BI Rate and CAR terhadap penyaluran kredit bank umum go public periode tahun 2012-2016. Journal of Management Diponegoro, 6(4), 942-952.

29. Hery. 2019. Manajemen Perbankan. Jakarta: PT Grasindo.

30. Hery. 2020. Dasar - Dasar Perbankan. Jakarta: PT Grasindo.

31. Idroes, Ferry N, 2011. Manajemen Risiko Perbankan. Jakarta: PT Raja Grafindo Persada.

32. Idachaba \& Ademola. 2019. Effect of Capital Adequacy, Credit Risk and Operating Efficiency on the performance of Commercial Banks in Nigeria. Financial Markets, Institutions and Risks. 3 (1) 104-114.

33. Ikatan Bankir Indonesia. 2014. Mengelola Kredit Secara Sehat. Edisi Pertama. Jakarta: PT. Gramedia Pustaka Utama.

34. Ikatan Bankir Indonesia. 2015. Manajemen Risiko. Edisi Pertama. Jakarta: PT. Gramedia Pustaka Utama.

35. Ikatan Bankir Indonesia. 2016. Strategi Manajemen Risiko Bank. Jakarta: PT Gramedia Pustaka Utama.

36. Ikatan Bankir Indonesia. 2018. Memahami Bisnis Bank. Jakarta: PT Gramedia Pustaka Utama.

37. Ismail. 2014. Perbankan Syariah. Jakarta: Kencana.

38. Kasmir. 2014. Analisis Laporan Keuangan. Jakarta: PT Raja Grafindo Persada.

39. Kasmir. 2016. Manajemen Sumber Daya Manusia (Teori and Praktik).Depok: PT Rajagrafindo Persada.

40. Kasmir. 2018. Pemasaran Bank Edisi Revisi. Jakarta: Prenadamedia Group.

41. Kasmir. 2019. Analisis Laporan Keuangan. Jakarta: PT Raja Grafindo Persada.

42. Kawshala \& Kushani. 2017. The Relationship between Corporate Governance and Firm Performance. Management and Administrative Sciences Review, 6(2), 73-84.

43. Kingu, Peter Stephen, Dr Salvio Macha \& Dr Raphael Gwahula. 2018. Impact of NonPerforming Loans on Bank's Profitability: Empirical Evidence from Commercial Banks in Tanzania. International Journal of Scientific Research and Management (IJSRM). 06(01) 71-79

44. Liyana, Liyah \& Emmy Indrayani. 2020. The Effect of Non-Performing Loan (NPL), Loan to Deposit Ratio (LDR) and Net Interest Margin (NIM) on Financial Performance (ROA) With Car as Intervening Variables. Asian Journal of Social Science and Management Technology. 2(2) 61-75.

45. Lotto, J. (2018). The empirical analysis of the impact of bank capital regulations on operating efficiency. International Journal of Financial Studies, 6(2), 34.

46. Malayu Hasibuan, 2017, Manajemen Sumber Daya Manusia, Jakarta: PT Bumi Aksara.

47. Mendoza, Rufo \& John Paolo R. Rivera. 2017. The Effect Of Credit Risk And Capital Adequacy On The Profitability Of Rural Banks In The Philippines. Scientific Annals of Economics and Business. 64 (1) 83-96.

48. Munawir. 2014. Analisis Laporan Keuangan. Yogyakarta: Liberty.

49. Permatasari \& Amboningtyas. 2017. The Influence of LDR, DPK, and NPL on ROA through CAR as Intervening Variable (Study on Conventional Bank Sub Sector Company 2012-2016 listed in BEI). Journal of Management, 3(3) 1-6.

50. Prastowo, Dwi. 2015. Analisis Laporan Keuangan Konsep and Aplikasi Edisi Ketiga. Yogyakarta: UPP STIM YKPN. 
51. Rahmah, Wahyuni. 2020. Effects Of Fundamental Finance On Roa At Conventional Commercial Banks Registered In Indonesian Stock Exchange. International Journal of Scientific \& Engineering Research. 11 (5) 1095-1100.

52. Sari, Ati Retna \& Sulistyo. 2018. Capital Adequacy Ratio, Loan to Deposit Ratio, and Efficiency Ratio on Return on Assets. Journal Annual Conference on Social Sciences and Humanities. 372-375.

53. Sari, Febi Nofita and Endri Endri. 2019. Determinants of Return on Assets (ROA) On Conventional Banks Listed On Indonesian Stock Exchange (IDX) Period 2013 - 2017. IOSR Journal of Business and Management. 21 (4) 52-62.

54. Setiani, Nur, Edward Gagah \& Azis Fathoni. 2018. Analysis of effect of CAR, NPF, FDR, and BOPO on ROA (Study at Shariah Commercial Bank in Indonesia period 2012-2016). Journal of Management. 4(4). 1-6.

55. Septiani \& Lestari. 2016. Pengaruh NPL and LDR terhadap Profitabilitas dengan CAR sebagai variabel mediasi pada PT BPR pasarraya kuta. E-Jurnal Manajemen, 5(1). 293 324.

56. Shabani, Halit, Fisnik Morina \& Valdrin Misiri. 2019. The Effect of Capital Adequacy on Returns of Assets of Commercial Banks in Kosovo. European Journal of Sustainable Development. 8(2) 201-208.

57. Soares, Pedro \& Muhammad Yunanto. 2018. The Effect Of NPL, CAR, LDR, OER And NIM To Banking Return On Asset. International Journal of Economics, Commerce and Management. 4(3) 40-55.

58. Sugiyono. 2016. Metode Penelitian Kuantitatif, Kualitatif and R\&D. Bandung: PT Alfabet.

59. Sugiyono. 2017. Metode Penelitian Kuantitatif, Kualitatif, and R\&D. Bandung: Alfabeta.

60. Surat Edaran Bank Indonesia No. 13/24/DPNP. (28 desember 2011). Tentang Perubahan Atas Peraturan Bank Indonesia No.11/1/PBI/2009 Tentang Bank Umum.

61. Supeni, N. 2019. Effect of NPL And LDR On ROA With CAR As An Intervening Variable. Journal Agribest. 3 (1) 14 -19.

62. Syamni, Ghazali \& Rasyimah dkk. 2018. Determination of Return on Assets of the Foreign Exchange Banks in Indonesia. Binus Business Review. 9 (3) 255-260.

63. Tangngisalu, Jannati, Rusdiah dkk. 2020. Effect of CAR and NPL on ROA: Empirical Study in Indonesia Banks. Journal of Asian Finance, Economics and Business. 7(6):9-18.

64. Tanjung, Putri Renalita Sutra. 2019. Analysis Of The Effect Of Operational Efficiency, Third- Party Funds And Non Performing Finance On Profitability In Sharia Banking In Indonesia. EPRA International Journal of Multidisciplinary Research (IJMR). 5 (11) 181191.

65. Udom, I. S., \& Eze, O. R. (2018). Effect of capital adequacy requirements on the profitability of commercial banks in Nigeria. International Research Journal of Finance and Economics, 165, 79-89.

66. Utari, Dewi, Ari Purwanti and Darsono Prawironegoro. 2014. Manajemen Keuangan Edisi Revisi. Jakarta: Mitra Wacana Media.

67. Wahrudin, Udin. 2020. Pengaruh Bopo and Non Performing Loan (NPL) Terhadap Return On Asset (ROA) PT. BPR Tata Asia Tahun 2012-2016. Jurnal Al Amar. 1 (3) 106-119.

68. www.bi.go.id. Diunduh tanggal 28, bulan April, tahun 2021.

69. www.bni.co.id. Diunduh tanggal 29, bulan April, tahun 2021.

70. www.bri.co.id. Diunduh tanggal 29, bulan April, tahun 2021.

71. www.btn.co.id. Diunduh tanggal 29, bulan April, tahun 2021.

72. www.bankmandiri.co.id. Diunduh tanggal 29, bulan April, tahun 2021.

73. Yusuf, Muhammad. 2017. Dampak Indikator Rasio Keuangan terhadap Profitabilitas Bank Umum Syariah di Indonesia. Jurnal Keuangan and Perbankan. 13 (2) 141-151. 